\title{
The challenges facing the global south: perspectives from the Philippines
}

\author{
Charmaine G. Misalucha*
}

\author{
*Correspondence: \\ charmaine.misalucha@dlsu. \\ edu.ph \\ De La Salle University, Manila, \\ Philippines
}

\begin{abstract}
International Relations scholarship highlights the differences of the countries in the global south. The postcolonial histories of countries herein give rise to unique experiences that push them to consolidate their states at the soonest time possible even as they are inextricably integrated in an international system that is biased towards the great powers. This double pressure either makes or break a state, and it is this tension that is the focus of the special issue. This concluding article offers a bird's-eye view of the nuances of the differences of the global south and the problems associated with it. I argue that while the differences may indeed be unique, not seeing beyond those is problematic. In line with this, I first acknowledge the differences the global south represents. I look at how the International Relations concepts of state, rational choice, and the international system are seen as inapplicable to the workings of the global south, and how this "misfit" is detected not only in the dynamics of Philippine foreign policy, but also in its relationships with various regional powers like the United States and China. I then turn to the problems associated with seeing only the differences of the global south. I highlight the concepts of mimicry and hybridity before examining the cases of the Philippines' labor conditions, human security for migrant workers, and disability-related issues. In all these, caution, mindfulness, and the need for dialogue are therefore called for.
\end{abstract}

Keywords: Global south, Philippines, Postcolonialism

\section{Background}

International Relations scholarship highlights the differences of the countries in the global south. The postcolonial histories of countries herein give rise to unique experiences that push them to consolidate their states at the soonest time possible even as they are inextricably integrated in an international system that is biased towards the great powers. This double pressure either makes or break a state, and it is this tension that is the focus of the special issue. How does a country in the global south deal with external and internal forces? What kinds of negotiations take place that allow a state to balance international and domestic pressures? More importantly, what strategies are used that reflect a state's own paradigms, worldviews, and realities?

To argue in favor of differences, however, is not unproblematic. For one, how different is "different"? While on one hand it may be accurate to say that the global south is easily distinguishable from the more affluent countries in the north, it is not too far a stretch

(C) 2015 Misalucha. This article is distributed under the terms of the Creative Commons Attribution 4.0 International License (http:// creativecommons.org/licenses/by/4.0/), which permits unrestricted use, distribution, and reproduction in any medium, provided you give appropriate credit to the original author(s) and the source, provide a link to the Creative Commons license, and indicate if changes were made. 
to also posit that so-called non-Western approaches have similarities with or overlap with "Western" International Relations concepts. If no approach can thus be considered as purely "Western," consequently then, no approach can likewise be seen as purely "non-Western." In addition, differences imply binary logics and stress the arbitrary lines between north and south, West and non-West. Doing so therefore reproduces modes of inclusion and exclusion.

As an exemplar to these nuances, the special issue offered perspectives from the Philippines. The country's colonial past and struggles towards independence make it a prime example for how a member of the global south participates in contemporary international affairs despite certain constraints. The objectives of the special issue are to interrogate the theoretical and empirical ways of studying the global south, to bring together the works of young scholars and tease out the nuances of the Philippines' role in the international and domestic levels of analysis, and to contribute to the conversation about the role of the global south in international relations.

This concluding article offers a bird's-eye view of the nuances of the differences of the global south and the problems associated with it. I argue that while the differences may indeed be unique, not seeing beyond those is problematic. In line with this, I first acknowledge the differences the global south represents. I look at how the IR concepts of state, rational choice, and the international system are seen as inapplicable to the workings of the global south, and how this "misfit" is detected not only in the dynamics of Philippine foreign policy, but also in its relationships with various regional powers like the United States and China. I then turn to the problems associated with seeing only the differences of the global south. I highlight the concepts of mimicry and hybridity before examining the cases of the Philippines' development strategies, labor conditions, human security for migrant workers, and disability-related issues. In all these, caution, mindfulness, and the need for dialogue are therefore called for.

\section{Differently different}

Pinar Bilgin points out how members of the global south are "differently different" (Bilgin 2012). Countries herein share the idea that certain concepts in traditional IR do not seem to "fit" with their historical and future trajectories (Neuman 1998). At the same time, members of the global south are "differently different" because their experiences, not least with the various regional powers and with each other, vary. The context and rationale of Philippine foreign policy certainly differs from, say, the foreign policy of Singapore. Moreover, the Philippines' relations with the United States, China, and Japan may indeed showcase asymmetry, but the levels or variance of asymmetry are still not quite the same. Being "differently different" thus echoes Homi Bhabha's "almost the same but not quite" adage (Bhabha 1994).

Three International Relations concepts qualify as a "misfit." The first has to do with the state. IR's Westphalian foundations celebrate the state as the basic unit of analysis and that, metaphorically, it is as monolithic as a billiard ball. With statehood comes sovereignty, that inviolable pillar of the modern international system. A state in the global south, however, may meet the basic tenets of statehood (territory, people, government, sovereignty), but its sovereignty is challenged by instances of intervention from the outside. This is because the statehood of a country in the global south still falls short of 
being fully consolidated. Mohammed Ayoob defines a prototypical "Third World" state as displaying the following characteristics: lack of internal cohesion, lack of definitive and legitimate state boundaries, vulnerability to internal and inter-state conflicts, uneven development, marginalization in international forums, and intervention by wealthier states, international organizations, or transnational and multinational corporations (Ayoob 1995). Whereas states in the global north are more outward looking in terms of the sources of security threats, for instance, those in the global south have a more inward orientation: insecurity for most of these states originate from within their borders instead of from without.

A second International Relations concept that does not seem to "fit" has to do with the value placed on rational choice. In a world of insecurity, it is only rational for states, whether they are strong or weak, to form alliances in order to minimize uncertainty. As with the concept of statehood, this too is not without problems. In the first place, what is considered rational may vary from culture to culture (Neuman 1998). For many in the global south, rationality may lie in embracing nationalism for purposes of consolidating their identity and hence, their statehood. Also, while alliances do work, arrangements like these between and among members of the global south are few and far between (Neuman 1998). The Philippines is a case in point: in the context of rising tensions in the South China Sea, it beefs up its alliance with the United States more so than its partnerships with the other claimants.

Third, the international system may undeniably be anarchic and the occurrence of interstate wars may but be typical. The case of the global south, however, depicts the more regular, even more expected, occurrence of intrastate wars. In this sense, it is not anarchy that constrains the external behavior of most states in the global south, but hierarchy (Escude 1998). The international system thus represents a paradox for countries in the global south, for while they may be predisposed towards the maintenance of the international order, their security and economic dependence on the north readily guarantees the perpetuation of a structure that "at the same time and at a different level they consider inequitable (Ayoob 1995).

The "misfit" of these concepts with the realities in the global south therefore underscores the power of the dominant paradigm in International Relations. The logic of power politics is representative only of a handful of (great) powers, and its pervasiveness results in the parochialism and provincialism of International Relations. This Americocentric and Eurocentric treatment of global affairs is detrimental not only to International Relations (the field of study), but also to international relations (the area of study) (Barkawi and Laffey 2006; Hobson 2012). It is precisely this that leads scholars to advocate worldviews that originate in the "non-Western" world. For instance, in acknowledging the colonial past, the struggles of the global south may be understood as a struggle for political, economic, and cultural emancipation (Puchala 1998). Meanwhile, focusing on culture, hybridity, and everyday life may account for alternative streams of knowledge (Tickner 2003). "Non-Western" traditions likewise have significant contributions in better explaining and understanding international relations (Acharya and Buzan 2009). To be fair, it must be acknowledged that some "Western" IR thinking carry perspectives of the "non-Western" world, such as dependency theory, world systems theory, postcolonialism, critical theories, postmodernism, poststructuralism, and constructivism. 
Although members of the global south have similar experiences in regard to how different they are from the more developed countries in the north, they are nonetheless "differently different." The articles in this issue showcase the variance of the Philippines' asymmetric relations with extra-regional powers. The Philippine experience is noteworthy, not least because of its role in the ongoing disputes in the South China Sea. How then does the Philippines negotiate with the great powers in the region? What role does the US-Philippine alliance play in the face of China's assertive moves? How do the disputes affect China-Philippine relations? Certainly, the Philippines' ability to manage its relations with the great powers is a testament to the challenges that a country in the global south faces.

As a jump-off point, this special issue focused first on the Philippines' relations with the bigger powers. US-Philippine relations demonstrate continued engagement as seen in the International Peace and Security Plan for the Philippines' credible external defense capability, the security sector reform, and further cooperation with other partners, including Australia, Japan, and South Korea. The article on China-Philippine relations, meanwhile, offered an analysis of the South China Sea dispute via asymmetric dilemmas involving variances in military forces, economic capacity, territorial size, and population. The rising tensions in the South China Sea can then be explained due to the failed management of asymmetric relationships. Coloring this is the factor of the US rebalance in Asia, which shifts the asymmetric bilateral dilemma of China-Philippine relations to a triangular entanglement between the US, China, and the Philippines.

In sum, the Philippines displays how a country in the global south maneuvers its way in the international system. Indeed, there are significant differences in the way it interacts with various actors. In the same way, some of the realities that the Philippines faces are contrary to or are not totally aligned with the more stringent concepts of International Relations. The concept of the state and the deployment of rational choice in the context of the international system all blend in and become more fluid when seen from the perspective of the Philippines. Sovereignty, which is an anchor of statehood, might not have been overstepped, but what became rational for a small state like the Philippines was not so much to exercise force to defend its sovereign integrity, but to learn how to hedge in an international system where great powers dominate. Seen in this light, a global south perspective is indeed different. However, focusing solely on what makes the Philippines different runs the risk of replicating the very modes of exclusion it tries to veer away from.

\section{The problem of difference}

Seeing differences matters. The global south and the global north oftentimes do exhibit stark contrasts. In the same way, International Relations concepts translate into something else when applied to the "non-Western" world (Inayatullah and Blaney 2004; Tickner and Waever 2009). Within the global south, however, there is-surprisingly-not enough difference (Tickner and Blaney 2012). There is, at best, limited difference. Several factors explain this, such as that there are some disciplinary parameters that simply work against diversity, and that International Relations, whether "western" or "nonWestern," remains state-centric (Tickner and Blaney 2012). But the crux of the problem of difference hinges on the concepts of mimicry and hybridity. 
The global south is said to mimic its counterparts in the north. By emphasizing difference, the implicit message is the need to bridge that gap via imitation: if only the global south were more like the north, then life would be better. Ayoob subscribes to the same logic: if only the "Third World" would consolidate its statehood like the "First World," then it could participate better and more fully in the international system, and it would no longer be in a security predicament (1995). The colonial discourse of mimicry therefore "emerges as the representation of a difference that is itself a process of disavowal" (Bhabha 1994, 86).

A second problem associated with highlighting difference is the notion of hybridity, which is the representation of an incomplete or contested global project: "Hybrid space is always contested-a push and pull between uniformity and difference. In this respect, hybridity might be celebrated in that it preserves diversity in the face of homogenizing practices (Tickner and Blaney 2012, 7). Hybridity enables the blending of categories. "West" and "non-West" are no longer distinct. Instead, they are suffused with ideas from both sides (Bilgin 2008).

Hybridity is reflected in three areas that the Philippines is facing: labor conditions, human security for migrant workers, and disability issues. Some of the questions that the articles posed were as follows. Given that one of the Philippines' most significant contributions to the global economy is its overseas labor, what are the conditions and migration patterns of overseas Filipino workers? In a similar vein, how does the Philippine state guarantee human security for Filipino migrants? An inclusive development strategy must likewise take into account persons with disabilities. In 2008, the Philippines ratified the UN Convention on the Rights of Persons with Disabilities. What have been accomplished so far, and what more needs to be done?

The article on labor conditions examined the plight of Filipino nurses in crisis zones like Libya. The authors find that while the migrants exercised risk calculation and reduction, they nonetheless tended to commit risk denial and embrace a false sense of empowerment and exceptionality. This provides a better justification for the Philippine government to take steps in implementing policies regarding the security of its migrant workers. The article on human security advocated institutionalizing human security policies and assumptions, but doing so carried risks. Ultimately, the solution would lay in the building of a national consensus on migration where stakeholders could participate in the debate. Finally, the article on disability issues evaluated whether the Philippines' electoral processes are disability inclusive. Using the disability convention policy framework, the author found that the Philippines needs to improve in both the institutional and social levels. In closing, while the differences of the global south matter, focusing only on what makes it distinct enables the practice of mimicry and underestimates the power of hybridity. The Philippine experience in the areas of labor, human security, and disability issues present the blending of arbitrary divisions.

\section{Conclusion}

The countries of the global south can be characterized as being caught between a rock and a hard place. On one hand, they are distinct from their counterparts in the global north. On the other hand, highlighting the difference undermines postcolonial realities. The Philippines captures these pressures succinctly. This begs several questions, 
however. Would the same be experienced by another member of the global south, for instance, countries like Ghana or Yemen or Ecuador? In what forms would "difference" take across these countries? Would there be significant differences among these similar countries? Asking these questions allows the possibility of dialogue not just between the global south and the global north, but more importantly, among the members of the global south themselves. International relations can then be more inclusive and more representative of what we call the "international."

\section{Competing interests}

The author declares that she has no competing interests.

Received: 28 July 2015 Accepted: 29 October 2015

Published online: 26 November 2015

\section{References}

Acharya, A., and B. Buzan (eds.). 2009. Non-Western international relations theory: Perspectives on and beyond Asia. New York: Routledge.

Ayoob, M. 1995. The Third World security predicament: State making, regional conflict, and the international system. Boulder: Lynne Rienner.

Barkawi, T., and M. Laffey. 2006. The postcolonial moment in security studies. Review in International Studies 32: 329-352.

Bhabha, H. 1994. The location of culture. New York: Routledge.

Bilgin, P. 2008. Thinking past "western"IR? Third World Quarterly 29(1): 5-23.

Bilgin, P. 2012. Security in the Arab world and Turkey. In Thinking International Relations Differently, ed. A.B. Tickner, and D.L. Blaney, 27-47. New York: Routledge.

Escude, C. 1998. An introduction to peripheral realism and its implications for the interstate system: Argentina and the Condor II Missile Project. In International relations theory and the Third World, ed. S.G. Neuman, 55-75. New York: St. Martin's Press.

Hobson, J.M. 2012. The Eurocentric conception of world politics. Cambridge: Cambridge University Press.

Inayatullah, N., and D.L. Blaney. 2004. International Relations and the problem of difference. New York: Routledge.

Neuman, S.G. 1998. International relations theory and the third world: An oxymoron? In International relations theory and the Third World, ed. S.G. Neuman, 1-29. New York: St. Martin's Press.

Puchala, D.J. 1998. Third world thinking and contemporary international relations. In International relations theory and the Third World, ed. S.G. Neuman, 133-157. New York: St. Martin's Press.

Tickner, A. 2003. Seeing IR differently: Notes from the third world. Millennium: Journal of International Studies 32(2): 295-324.

Tickner, A.B., and D.L. Blaney (eds.). 2012. Thinking international relations differently. New York: Routledge.

Tickner, A.B., and O. Waever (eds.). 2009. International relations scholarship around the world. New York: Routledge.

\section{Submit your manuscript to a SpringerOpen ${ }^{\circ}$ journal and benefit from:}

- Convenient online submission

- Rigorous peer review

- Immediate publication on acceptance

- Open access: articles freely available online

- High visibility within the field

- Retaining the copyright to your article

Submit your next manuscript at $>$ springeropen.com 